\title{
Władysław Krawczyk
}

\section{Rola misji kanonicznej w realizacji prezbiterium diecezjalnego}

Prawo Kanoniczne : kwartalnik prawno-historyczny 23/3-4, 3-9

1980

Artykuł został zdigitalizowany i opracowany do udostępnienia w internecie przez Muzeum Historii Polski w ramach prac podejmowanych na rzecz zapewnienia otwartego, powszechnego i trwałego dostępu do polskiego dorobku naukowego i kulturalnego. Artykuł jest umieszczony w kolekcji cyfrowej bazhum.muzhp.pl, gromadzącej zawartość polskich czasopism humanistycznych i społecznych.

Tekst jest udostępniony do wykorzystania w ramach dozwolonego użytku. 


\section{KS. WEADYSEAW KRAWCZYK}

\section{ROLA MISJI KANONICZNEJ W REALIZACJI PREZBITERIUM DIECEZJALNEGO}

Treść: Wstęp. 1. Misja kanoniczna a kapłani diecezjalni. - 2. Misja kanoniczna a kapłani zaikonni. - Zakończenie.

\section{Wstęp}

Jezus Chrystus w określonym czasie dokonal odkupienia wszystkich ludzi. Aby jednak odkupienia dokonać w każdym czlowie$\mathrm{ku} \dot{z} y j a ̨ c y m$ w różnych odcinkach czasu historii posłał grupe ludzi: kolegium apostolskie.

Posłannictwo to Chrystus przekazał nie poszczególnym apostołom, ale „wszystkim wspólnie... dał przykazanie, nakładając na nich wspólny obowiązek" (officium) ${ }^{1}$. Nadto Chrystus obiecal swoją czynną obecność i zesłał na to Kolegium Ducha Swiętego, dzięki czemu kolegium to jest nieomylne i trwa ". „Źeby zaś episkopat byl jeden $i$ niepodzielny, postawil nad innymi apostołami swiętego Piotra i w nim ustanowił trwałą i widzialną zasadę i fundament jeđności i wspólnoty" 3 .

A więc $z$ pozytywnej woli Jezusa Chrystusa nosicielem posłannictwa Bożego w świecie jest kolegium apostolskie, które tę misję przekazało kolegium biskupów jako prawowitemu swemu następcy $^{4}$.

\section{Misja kanonicza a kapłani diecezjalni}

Obecnie kolegium biskupów, aby mogło spełnić na siebie nalożoną misję zbawienia każdego czlowieka w czasie $i$ przestrzeni, musi w tym celu wcielić nowe członki do swego organizmu, żeby $w$ ten sposób mogła trwać sukcesja apostolska na całej ziemi i wśród wiszystkich ludzi. „Kolegium realizuje wcielenie no-

$1 \mathrm{KK}$ n. 23.

2 KK n. 19.

$3 \mathrm{KK}$ n. 18; Por. Sobór Watykański I. Konistytucja dogmatyczna o Kościele, Pastor Aeternus, w :Denz. 1821 (n. 3050).

${ }_{4} \mathrm{Jimenez-Urresti}$ T., Postannictwo Boże $w$ historii a misja kanoniczna, Concilium 1-10 (1968) 439. 
wych czlonków przez specyficzny akt sakramentu kapłaństwa, które dokonuje się - od swoich początków - przez włożenie rąk. A wcielając w ten sposób nowego członka, czyni go uczestniczącym, solidarnym, współodpowiedzialnym, albo lepiej uczestniczącym w powszechnej misji kolegialnej, to jest funkcji (munus), w obowiązku (officium) i w trosce (cura) misyjnej, jak również $w$ funkcjach, oficjalnym sprawowaniu urzędu, w powadze i władzy duchownej kolegium, nadanych razem ze wspólną misją kolegialną" 5 .

Działalność nowego członka włączona do kolegium, aby mogła być pożyteczna, winna działać w podporządkowaniu, w organizacji i misyjnym programie duszpasterskim, ustalonym przez kolegium.

$\mathrm{Na}$ plaszczyżnie kanonicznej w konkretnym działaniu historycznym kolegium biskupie włącza poszczególnego członka do konkretnego zadania, w konkretnych warunkach i w konkretny sposób. Ten konkretny przydział zadań i konkretne historyczne zlecenie nazywa sie misją kanoniczna. Jest ona nadto stwierdzeniem zachowania łączności czyli ,communio" z kolegium i jego glową ${ }^{\circ}$.

Każdy biskup z racji pelni kapłaństwa włączony jest do tegoż kolegium jako czlonek pełnoprawny, natomiast kapłani nie posiadający tej pekni są tylko członkami pomocniczymi. Niemniej jednak $z$ racji uczestnictwa $w$ tym samym kaplaństwie Chrystusowym wszyscy kapłani są w służbie posłania Bożego. powszechnego, w którym uczestniczą i ich kapłaństwo nastawione jest na służbe Kościoła powszechnego. Ta inkardynacja teologiczna przekształca się przez misję kanoniczną w inkardynację kanoniczną, skierowaną wprost do danego Kościoła partykularnego. A więc misja kanoniczna jest aktem prawnym, dzięlki któremu aktualizuje się sakramentalne uczestnictwo kapłanów w świętych zadaniach biskupów, mianowicie w nauczaniu, uświęcaniu i w pasterskim kierowaniu w danym Kościele partykularnym i włącza tym samym poszczególnego kapłana do danego prezbiterium diecezjalnego.

Misja kanoniczna jednak nie wydaje się stanowić jedynego kryterium przynależności do danego prezbiterium diecezjalnego. Bowiem kapłan inkardynowany do jakiejś diecezji, gdy zostaje przez swego biskupa pozbawiony misji kanonicznej, nie traci tym

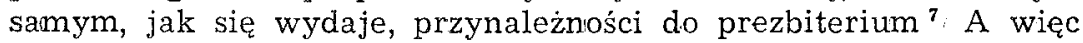

$5 \mathrm{Jimenez}-\mathrm{U}$ rresti T., art. cyt. s. 440.

6 Por. KK n. 21; DK n. 7; Ż u r ow ski M., Uprawnienie do wspótuczestnictwa w koscielnej wspólnocie wspólnot - "Ius ad communionem", Warszawa 1977, s. 294 i 296 (maszynopis).

7 Por. Ż u row ski M., Prawne aspekty Konstytucji "Lumen Gentium", Prawo Kanoniczne 10 (1967) 1-2, s. 71. 
nie tylko misja kanoniczna ale również i inkardynacja stanowi kryterium przynaleźności do kleru diecezji. Nadto Sobór Watykański II wprowadził nowe kryterium przynależności kapłana do prezbiterium Kościoła partykularnego przez wprowadzenie nowej instytucji prawnej, a mianowicie ,przydzielenia" (addictio) ${ }^{9}$. Wobec tego biskup na terenie Kościoła partykularnego skupia wokól siebie „wszystkich kapłanów diecezjalnych, to jest zarówno kapłanów do jego diecezji inkardynowanych, jak i tych, którzy będąc inkardynowani do innej diecezji lub prałatury są przydzieleni (addicti) do pracy w jego diecezji na pewien okres czasu" 10 .

\section{Misja kanoniczna a kaplani zakonni}

$\mathrm{Na}$ podstawie tego, co wyżej zostało powiedziane, wydawać by się moglo, że do grona kapłańskiego tworzącego prezbiterium diecezji, należa tylko i wyłącznie kapłani diecezjalni. Tymczasem w konstytucji dogmatycznej o Kościele czytamy, że ,z kolegium biskupim związani są ściśle $z$ tytułu kapłaństwa i świętego posługiwania wszyscy kapłani, zarówno diecezjalni, jak i zakonni, i stosownie do swego powołania oraz otrzymanej laski służą dobru całego Kościoła" "i . A więc Sobór Watykański II wyraźnie stwierdza, że do prezbiterium diecezji należą nie tylko kapłani diecezjalni, ale również i zakonni.

Jednak powistaje pewna trudność w interpretacji tej wypowiedzi Soboru oraz $w$ odpowiedzi na pytanie, w jakim sensie naleza do prezbiterium diecezjalnego kapłani zakonni, skoro posiadaja „swoje własne konstytucje zakonne, swoje własne zadania tak natury indywidualnej (ascetycznej), jako i wspólnotowej (exempti, non exempti)" 12. Trudność tę powiększają niedostatecznie jasne teksty soborowe $w$ tej sprawie, a $z w ł a s z c z a$ szereg odpowiedzi udzielonych przez Komisje soborowe, zajmujące się tym problemem, „na liczne modi zgloszone przez ojców soborowych do tekstu Konstytucji dogmatycznej o Kościele i do tekstu dekretu o pasterskich zadaniach biskupów w Kościele" 13.

${ }^{8}$ Por. Kan. 111-117.

9 Por. DB n. 28.

10 Pieronek T., Rada Kaplańska wyrazem soborowej odnowy, Prawo Kanoniczne 12 (1969) 3-4, s. 13; por. C arli M., Ufficio pastorale dei vescovi e Chiese orientali cattoliche. Genesi storico-dottrinale. Testo latino e traduzione italiana. Esposizione e commento Motu Proprio „Ecclesiae sanctae”, ed. Elle Di Ci, Torino 1967, s. 339, 372-373 (Cytuję za: Pieronek T., art. cyt., s. 13, przyp. 55).

$11 \mathrm{KK}$ n. 28.

12. Łukaszyk R., Troskliwi wspótpracownicy urzędu biskupiego, Collectanea Theologica 38 (1968) IV, s. 30.

${ }_{18}$ Pieronek T., art. cyt., s. 14; por. Rambaldi J., Fraternitas 
Niektórzy $z$ kanonistów rozwiązanie tego problemu widzą $w$ przyjęciu dwóch znaczeń terminu ,prezbiterium": znaczenia szerszego i ściślejszego. W znaczeniu szerszym przez prezbiterium należy rozumieć wszystkich kapłanów zarówno diecezjalnych jak i zakonnych, a podstawą tak zrozumianej wspólnoty jest wyłącznie kapłaństwo Chrystusowe i uczestnictwo w Jego misji. Tak rozumiane prezbiterium za podstawę miałoby wyłącznie prawo Boże. Natomiast przez prezbiterium w znaczeniu ścisłym należy zrozumieć kapłanów diecezjalnych, którzy z danym Kościołem partykularnym związani są nie tylko z tytułu prawa Bożego ale również i kościelnego ${ }^{14}$.

Przeciwko takiemu rozumieniu prezbiterium diecezjalnego, które wedkug innych kanonistów jest nie do przyjęcia, stawiane są trudności. Po pierwsze Sobór nigdzie sam nie stawia rozróżnienia na prezbiterium $w$ ścisłym i szerszym znaczeniu, a po drugie, przy założeniu słuszności tej opinii, biskup diecezji, gdzie pracują wyłącznie kapłani zakonni, nie posiadałby prezbiterium - a to jest sprzeczne $z$ pojęciẹm Kościoła i nauką Soboru o kapłaństwie ${ }^{15}$.

Aby problem przynależności kapłanów zakonnych do prezbiterium diecezjalnego mógł być właściwie rozwiązywany, wydaje się, że należy w rozwiązywaniu go iść drogą bardziej teologiczną niż kanoniczną, chociaż przy założeniu, że do prezbiterium Kościoła partykularnegio nalezą tylko kapłani diecezji, z punktu widzenia prawnego takie rozwiązanie jest zupełnie sluszne i konsekwentnie oparte na instytucji inkardynacji. Dekret o pasterskich zadaniach biskupów w Kościele mówi, że wszyscy kapłani, nie tylko diecezjalni ale również zakonni 16, zarówno wyjęci, jak niewyjęci 17 są w zasięgu władzy ordynariusza, który obejmuje wszystko to, co dotyczy kultu publicznego, troski duszpaisterskiej, gloszenia słowa Bożego, wychowania religijnego oraz wszystkie te sprawy, które są związane z realizacją posłannictwa apostolskiego.

„Powyższe czynności wypływają u kapłanów zakonnych nie $z$ ich statusu zakonnego, ale kapłańskiego. Jako czynności ściśle kapłańskie mogą być wykonywane tylko w ścisłej więzi z biskupem. Stąd też powiedzieć można w świetle tegoż dekretu, że Sobór dokonał sprecyzowania następującej zasady: każdy kapłan,

sacramentalis et presbyterium in Decreto "Presbyterorum Ordinis", n. 8, Periodica de re morali canonica liturgica 3 (1968) $331-350$.

$14 \mathrm{R}$ a $\mathrm{m} \mathrm{b}$ a $1 \mathrm{~d}$ i J., art. cyt., s. $347-348$.

${ }^{15}$ Lecuyer J., L'Eglise continue l'oeuvre sacerdotale du Christ, La Vie Spirituelle 47 (1965) 283; Tarancon V., El sacerdocio a la luz del Concilio Vaticano II, Salamanca 1966, s. 102. (Cytuję za Rambaldi J., art. cyt., s. 344 , przyp. 43 ).

16 DB n. 28.

17 DB n. $35 \S 4$. 
zarówno diecezjalny, jak i zakonny, $\mathrm{z}$ konieczności przynależy do prezbiterium diecezji i pozostaje $w$ ścisłej więzi $z$ biskupem oraz podlega biskupowi we wszystkim, co dotyczy budowania Kościoła diecezjalnego. Egzempcja bowiem wcale nie oznacza nie zależności od biskupa ${ }^{18}$, gdyż łączność $\mathrm{z}$ papieżem jako glowa kolegium biskupiego powstaje i zwiększana jest dzięki łączności $z$ biskupem jako glową kolegium diecezjalnego ${ }^{19}$. Reguła zakonna natomiast $\mathrm{i}$ wszelkie przywileje - jak stwierdza w komentarzu A. Grillmeier ${ }^{20}$ - nie maja wcale na celu wyizolowania kapłanów zakkonnych z Kościoła, ale jeszcze głębsze ich włączenie w kościelną wspólnotę kapłańską. Można powiedzieć, że ten właśnie fakt włączenia we wspólnotę stanowi także punkt wyjścia dla adnowy życia zakonnego $\mathrm{w}$ duchu wskazań Soboru. Prezbiterium więc diecezji to wspólnota kaplanów diecezjalnych jak i zakonnych z biskupem na czele" ${ }^{21}$.

Niemniej Sobór nie zmienia zasady, że kapłani zakonni nie są inkardynowani do diecezji, ale do zakonu ${ }^{22}$. A więc podlegając od strony przynależności do prezbiterium diecezji biskupowi, nie przestają nadal podlegać, jak to było dotychczas w prawie kodeksowym, swoim przełożonym zakonnym $\mathrm{z}$ racji przynależności do zakonu ${ }^{23}$, pełniąc $\mathrm{w}$ Kościele, sobie właściwą rolę charyzmatyczną ${ }^{34}$. Jednakże, ,biorąc pod uwagę charakter właściwy każdemu zakonowi winni chętnie przystępawać również do zewnętrznych dziel apostolatu" ${ }^{25}$. Nadto w dekrecie tym czytamy: „Kapłani zakonni, wyświęceni do zadań kapłańskich w tym celu, by być troskliwymi w.spólpracownikami biskupiego stanu, są dziś w możności, wobec wzmagania się zapotrzebowań dusz, służyć więlkszą pomocą biskupom. Dlatego trzeba powiedzieć, że w pewien przewidziany sposób przynależą do kleru diecezji, skoro mają udział $w$ trosce o dusze $i$ wypełnieniu dziel apostolatu pod władzą biskupów" ${ }^{26}$. Inaczej więc mówiąc należy postawić następującą regułę: „Kàpłani zakonni o tyle należą do kleru

18 Por. DB. n. $35 \& 3$.

19 Giblet.J., Die Priester des ,zweiten Grades", w: De Ecclesia, II, Frankfurt am Main 1966, s. 209-210.

20 Grillmeier A., Kommentar zum Artikel 28 der Kirchenkonstitution, w: Das Zweite Vatikanische Konzil, I, Freiburg 1966, s. 255.

$21 \mathrm{Eu} \mathrm{k}$ a s z k R., art. cyt., s. 31 .

22 Por. Kan. 115 i 585.

23 Por. Kan. 630-631; DB. n. 35.

$24 \mathrm{KK}$ n. 44; por. B ou chet $\mathrm{P}$., La hierarchie et l'apostolat des religieux, Revue de Droit Canonique 2-3 (1968) 106-111; Gu it t on J .Kościół wspótczesny, Warszawa 1965, s. 247.

${ }_{25} \mathrm{DB}$ n. 33 ; por. Proesmans H., Zakonnicy $w$ pracy duszpasterskiej diecezjalnej $i$ parafialnej, Concilium 1-10 (1966-67) 487-492.

26 DB n. 34. 
diecezji, o ile (quatenus) biora udział w pracy duszpasterskiej lub zajmują się apostolstwem" 27.

Powstaje pytanie w jaki sposób biskup może wezwać kaplana zakonnego do pracy duszpasterskiej lub dziel apostolatu w danym Kościele partykularnym. $\mathrm{Na}$ to pytanie odpowiada dekret Christus Dominus bardzo ogólnie, a mianowicie to wezwanie ma się odbyć „,W sposób prawowity" (legitime) ${ }^{28}$, czyli ,zakonników nie można wezwać inaczej, jak za pośrednictwem prawowitych przełożonych i z zachowaniem przepisów prawa" ${ }^{29}$.

Reasumując powyższe rozważania należy postawić twierdzenie: Kapłan zakonny wchodzi do prezbiterium diecezjalnego poprzez otrzymanie od biskupa misji kanonicznej, poprzez którą staje się urzędowym i bezpośrednim jego współpracownikiem w paster-. skiej posłudze nauczania, uświęcania i rządzenia ${ }^{30}$.

\section{Zakończenie}

A więc diecezjalne prezbiterium w Kościele partykularnym obejmuje nie tylko kapłanów diecezjalnych inkardynowanych czy diecezji przydzielonych, ale i kapłanów zakonnych posiadających misję kanoniczną. Z całości naszych rozważań widać, że inkardynacja, przydzielenie i misja kanoniczna, w oparciu o element zasadniczy sakramentu kapłaństwa, stanowi o przynależności do danego prezbiterium partykularnego, dzięki którym u każdego kaplana diecezjalnego i zakonnego, aktualizuje się sakramentalne uczestnictwo w świętych zadaniach biskupa, a więc w nauczaniu, uświęcaniu i pasterzowaniu.

Nadto należy stwierdzić, ̇̇e w świetle ustawodawstwa posoborowego przynależność do prezbiterium diecezjalnego, chociaż wynika $z$ różnych instytucji kanonicznych, jest analogicznie podobna, a nawet tożsama, gdy chodzi o kapłanów do diecezji przydzielonych i kapłanów zakonnych posiadających w danej diecezji misję kanoniczną.

\section{De missione canonica in realisatione presbyterii dioecesani}

Ex Codice Iuris Canonici patet sacerdotes dioecesanos solum ad presbyterium dioecesanum pertinere (can. 111). Aliam doctrinam in hac re Concilium Vaticanum II exponit. Ex constitutione Lumen gentium.

$27 \mathrm{P}$ i e ronek T., art. cyt., s. 15.

28 DB n. 35.

29 Sacrosanctum Oecumenicum Concilium Vaticanum Secundum, Schema. Decreti De pastorali episcoporum munere in Ecclesia, Textus emendatus et Relationes, Typis Polyglottis Vaticanis 1964, s. 72.

${ }^{30}$ Por. $\mathrm{R}$ ous e a u J., De relationibus iuridicis religiosorum cum. sacra hierarchia recognoscendis, Apollinaris 40 (1967) 250 ; L ecu y e r J., dz. cyt., s. 282-183; kan. 109. 
(n. 28) et decreto Christus Dominus (n. 28) evadit, ut ad presbyterium dioecesanum pertineant etiam ii sacerdotes, qui ad curam animarum temporalem alicui Ecclesiae particulari addicti sunt necnon sacerdotes religiosi quamvis sollicitudinem animarum cum episcopo in eius dioecesi habentes.

Auctor in hoc articulo voluit responsionem dare in quaestione: quo modo sacerdotes dioecesi ad cura animarum temporalem addicti et religiosi pertinere possunt ad presbyterium dioecesanum alicuius Ecclesiae particularis ratione incardinationis in sua dioecesi vel inscriptionis in sua religione manentes?

Primum varias opiniones canonistarum in hac quaestione dissertantium exponit denique dat opinionem suam. Secundum eam opinionem instrumentum incorporationis ad presbyterium dioecesanum missio canonica est propter quam participatio sacerdotum sacramentalis in sacris muneribus episcopi actuatur. Adiuncti unitate unius Sacerdotii Christi et participantes in muneribus sacris unius episcopi unum presbyterium dioecesanum atque unam familiam sacerdotalem constituunt.

In luce doctrinae Concilii Vaticani II ad presbyterium dioecesanum pertinent non solum sacerdotes dioecesi incardinati sed etiam ei addicti necnon religiosi, qui in ea missionem canonicam habent. 